\title{
The Influence of National Music on the Reform of College Music Piano Teaching
}

Qinyi Chang

School of Music, Shanghai University, Shanghai 200444, China.

Abstract: The unique value connotation and emotions exhibited by ethnic music itself can play a positive role in improving people's artistic cultivation and aesthetic level. Piano classroom is the main content of music education in colleges and universities. In order to ensure the orderly conduct of classroom teaching activities, teachers can combine the actual teaching and actively introduce folk music into it, so that students can learn through the content of classroom knowledge, which guarantees the interest of learning Enhancement can also establish the correct sense of pride of the clan, and then grow into the music talents that the country needs.

Keywords: Reform Influence; Folk Music; Piano Teaching; University Education

There are many ethnic minorities in my country, and the customs and regional cultures exhibited by different ethnic groups, as part of my country's outstanding ethnic culture, often enable people to dig out more unique values of ethnic culture in the process of continuous exploration. Music is an important way for different peoples to express their emotions and show their own culture. When teachers participate in music piano lessons, the addition of national music can not only enable students to expand their knowledge reserves while learning knowledge, but also be able to explore different nationalities. In the process of different forms of music, it stimulates the enthusiasm of participating in classroom knowledge learning, so as to achieve the purpose of improving teaching quality. This article starts with the importance of integrating ethnic music into the classroom of piano classrooms in colleges and universities, and looks for specific influences, hoping to provide references for other music teachers.

\section{The importance of integrating national music in piano classes in colleges and universities}

\subsection{Music inheritance needs}

With the development of the economy and the innovation of education reform, people gradually realize that the positive significance of art education to students' emotional concepts, aesthetic literacy and values is more important. Therefore, colleges and universities have attached great importance to the promotion of music education reform, hoping to enable students to participate in better piano classroom learning activities, grow into music talents who can meet the development requirements of the country, and contribute their own strength to the inheritance of art and culture. At the same time as China has a long history, the value of national culture itself is more and more worth digging into. Therefore, the introduction of national music culture in the piano classroom teaching activities of teachers can not only accelerate the inheritance of national music, but also In the process of extending students' knowledge reserves and mobilizing their learning enthusiasm, students can take the initiative to shoulder the mission of inheriting excellent music culture under the inspiration of national pride.

\subsection{Mobilize students' musical emotions}

Piano teaching content originated in western countries, so as a kind of foreign music culture, many students in the process of knowledge learning, because of the lack of understanding of the cultural value inherent in the piano itself, often cannot perform themselves well when performing The integration of emotions makes it difficult to improve the quality of learning.

Copyright(C 2020 Qinyi Chang

doi: $10.18686 /$ ahe.v4i10.2878

This is an open-access article distributed under the terms of the Creative Commons Attribution Non-Commercial License (http://creativecommons. org/licenses/by-nc/4.0/), which permits unrestricted non-commercial use, distribution, and reproduction in any medium, provided the original work is properly cited. 
National music originated from China's excellent culture is more likely to stimulate students' musical emotions. Therefore, when conducting piano classroom teaching activities, teachers can not only break cultural barriers through the integration of national culture, so that students can better complete the learning of knowledge, Can also bring the emotion of music into the performance. This not only enables students to master basic knowledge and performance techniques, but also to ensure the improvement of learning efficiency, but also in the process of mobilizing their musical emotions, so that students can play a more vital music through the subjective initiative.

\section{The specific influence of integrating national music in piano classes in colleges}

\subsection{Stimulate national emotions}

Traditional piano teaching in colleges and universities uses Western culture as the teaching carrier, so although students can learn music knowledge, it is difficult to introduce full emotion into music performance. Therefore, the integration of folk music in piano teaching can enable students to establish a firmer sense of national pride while grasping the context of national culture, and in the continuous innovation and development, introduce folk music culture into piano performance, and then achieve The purpose of improving learning quality. Therefore, when teachers carry out music classroom teaching activities, in addition to the need to impart basic knowledge to students, they also need to guide students' values. In this way, students can feel the cultural value and artistic essence of the national music culture through the participation of the piano classroom, and in the process of constantly stimulating national emotions, they become practitioners who firmly promote cultural development.

\subsection{Inheritance of cultural values}

Music is always an important form of expression in the art field, so music is not only a means of expressing the author's emotions, but also can bear the responsibility of inheriting culture. For college students in the new era, while accepting foreign cultures, they also need to pay close attention to the outstanding achievements of national culture in order to establish cultural self-confidence in the process of learning from each other's strengths, and promote the better development of national culture. Therefore, when introducing piano music, teachers can not only enable students to expand their knowledge reserves, but also help them to take the responsibility of inheriting culture while understanding the essence of folk music culture, and then grow to be in line with national development. The concept of high-quality music talents.

\subsection{Optimize teaching content}

In order to ensure the orderly progress of the piano classroom education, when teachers design the teaching activities, they optimize the content of the lectures and effectively integrate folk music and piano knowledge, which not only enables students to exercise while enriching music learning materials My own performance skills and rich knowledge reserve, while feeling the cultural differences between China and the West, I also found different inspirations for music performance. This can not only promote the individualized development of students well, but also mobilize their learning initiative, so that students can feel the essence of national cultural value, and then get a more comprehensive development in the continuous learning process.

\section{Conclusion}

Piano classroom is an important part of music education. In order to ensure the smooth implementation of teaching work, teachers need to change backward teaching methods, through careful analysis of national music culture, and the enthusiasm, speculation, aesthetic literacy and learning ability of college students. Combine and introduce it into the piano classroom in different ways. This can not only achieve the purpose of effectively inheriting the culture, but also enable students to not only ensure the improvement of learning quality in the process of enhancing learning initiative, but also stimulate national pride, and thus achieve more comprehensive development in continuous progress.

\section{References}

1. Li X. Exploration of the application of Guizhou minority music in piano teaching in colleges and universities—-Taking Guizhou University Conservatory of Music as an example. Northern Music 2020; (06): 123-124.

2. Zhao F. Thoughts on the fusion of music major courses in ordinary colleges and universities — Taking the piano course of music major in Anhui Normal University Wanjiang College as an example. Journal of Chuzhou University 2020; 22(01): 124-128.

3. Ying J. On the Differences in Piano Teaching of Music Majors between Chinese and American Universities— — Taking South Alabama University and Shaoxing College of Arts and Sciences as Examples. Educational Theory and Practice 2019; 39(36): 61-62. 